\title{
Review Board (Vol. 13)
}

Susann Allnutt, Education Consultant

Vera Caine, University of Alberta

Simmee Chung, Concordia University of Edmonton

Diane Conrad, University of Alberta

Jean Fillatre, Education Consultant

Corrine Glesne, University of Vermont

Janice Huber, University of Alberta

M. Shaun Murphy, University of Saskatchewan

Lesley Pasquin, Education Consultant

Stefinee Pinnegar, Brigham Young University

Gomatee Ramnarine, University of Trinidad and Tobago

Abigail Shabtay, York University

Carolyn Sturge Sparkes, Memorial University

Sean Wiebe, University of Prince Edward Island 